\title{
Productivity of long-term grazing treatments in response to seasonal precipitation
}

\author{
DANIEL G. MILCHUNAS, JAMES R. FOR WOOD, AND WILLIAM K. LAUENROTH
}

\begin{abstract}
Authors are research associate, Department of Range Science and Natural Resource Ecology Laboratory, Colorado State University, Ft. Collins 80523; range scientist (deceased), USDA-ARS Crops Research Laboratory, USDA-ARS, I701 Center Ave., Ft. Collins, Colo. 80523; and professor, Department of Range Science and Natural Resource Ecology Laboratory, Colorado State University, Ft. Collins 80523.
\end{abstract}

\begin{abstract}
Estimates of forage production for long-term ungrazed, lightly, moderately, and heavily grazed treatments $(0,20,40,60 \%$ removal of annual forage production) established in 1939 in shortgrass steppe communities were subjected to multiple regression analyses to assess long-term temporal trends resulting from grazing and short-term sensitivities to abiotic factors. Average production based upon all data from $1939-1990$ was $75,71,68$, and $57 \mathrm{~g} \mathrm{~m}^{-2} \mathrm{yr}^{-1}$ for ungrazed, lightly, moderately, and heavily grazed treatments, respectively. Variability in forage production was explained mostly by cool-season precipitation, and magnitude of forage production was more sensitive to annual fluctuations in precipitation than to long-term grazing treatments. Production per unit increase of precipitation was greater for cool-season than warm-season precipitation, but only when cool-season precipitation was above average. This was attributed to differences in evaporative demand of the atmosphere resulting in different utilization-efficiencies of small and large rainfall events in the 2 seasons. Based upon a regression model constructed using data from 1939 through 1962, forage production was not affected by grazing to 20 to $35 \%$ removal. For pastures of average relative productivity, grazing at $60 \%$ level of consumption for 25 years resulted in a $3 \%$ decrease in forage production in wet years and a $12 \%$ decrease in dry years. Estimates of productivity after 50 years of heavy compared to light grazing treatment were -5 and $-18 \%$ for wet and average years of precipitation, respectively.
\end{abstract}

Key Words: abiotic versus biotic controls, forage production, grazing intensities, rain-use-efficiency, semiarid grassland, shortgrass steppe

Le Houérou (1984) suggested that "vegetation condition" due to grazing management seems to influence the rain-use efficiency of plant communities at least as much as aridity. Greater quantity and lower variability in annual production was observed for pristine versus grazed vegetation across a range of grasslands (Le Houérou et al. 1988). However, the semiarid shortgrass steppe has a long evolutionary history of grazing by large herbivores and does not respond to grazing in a manner similar to that of many other plant communities (Milchunas et al. 1988). Species composition of ungrazed communities is more similar to that of disturbed communities than is species composition of heavy grazed communities (Milchunas et al. 1990). Does this grassland display the same

\footnotetext{
The CPER is administered by the Rangeland Resource Research Unit of the USDA Agricultural Research Service. Mary Calvert Ashby (USDA-ARS Crops Research Lab) compiled much of the early, unpublished forage production data, and W.J. Parton (Natural Resource Ecology Laboratory, Colorado State University) provided long-term precipitation and temperature data. This is a contribution of the Shortgrass Steppe Long Term Ecological Research Program (NSF BSR-8114822), the USDAARS, and the Colorado Agricultural Experiment Station (1-57661).

Manuscript accepted 16 Oct. 1993.
}

resistance to grazing in long-term forage production as it does in species composition? Does production in different grazing intensity treatments track annual fluctuations and seasonal timing in precipitation similarly?

Forty percent of the variation in annual forage production across a wide range of moderately grazed pastures could be explained by annual precipitation (Lauenroth and Sala 1992). The difference between a wet versus a dry year in the shortgrass steppe is a function of a few large events, but the majority of rainfall in either dry or wet years comes in small events (Sala and Lauenroth 1982, Sala et al. 1992). There are reasons to believe that grazing intensity treatments may interact with fluctuations in precipitation, thereby differentially affecting production. In the shortgrass steppe, plant basal cover is greater, litter cover is less (Milchunas et al. 1989), and root biomass distributions more uniform spatially, potentially allowing a more intensive exploration of the soil volume (Milchunas and Lauenroth 1989), in heavily grazed than ungrazed treatments. These structural differences between grazing treatments may differentially affect precipitation-use-efficiency in dry versus wet years.

In addition to annual fluctuations, long-term data sets are conducive to addressing questions concerning time-lag effects. While production of individual tillers may be closely related to currentyear precipitation, a dry year or a series of dry years may reduce basal cover, thereby constraining production in subsequent years even when conditions are favorable for growth. A better understanding of plant growth relationships to current- and previousyear conditions can help in formulating guidelines for proper stocking-rate management.

Our objectives were to assess long-term trends in forage production in relation to grazing intensity treatments. We focus on potential interactions of the gazing treatments with efficiency in utilizing current-year seasonal precipitation, the effects of previous years' precipitation on current-year production, and the relative importance of climatic, edaphic, and biotic controls.

\section{Materials and Methods}

The Central Plains Experimental Range (CPER) is located in north-central Colorado $\left(40^{\circ} 49^{\prime} \mathrm{N} 107^{\circ} 47^{\prime} \mathrm{W}\right)$. Vegetation is dominated by blue grama (Bouteloua gracilis (H.B.K.) Lag.) and buffalo grass ( Buchloe dactyloides (Nutt.) Engelm.), with plains pricklypear (Opuntia polyacantha Haw.), scarlet globemallow (Sphaeralcea coccinea (Pursh) Rydb.), and fringed sagewort (Artemisia frigida Willd.) consistent components. Basal cover is typically 25-35\%, 90\% of which is blue grama (Milchunas et al. 1989). Precipitation averages $32.1-\mathrm{cm} \mathrm{yr}^{-1}\left(9.8-\mathrm{cm} \mathrm{yr}^{-1}\right.$ standard deviation), ranging from 22.6 to $47.9 \mathrm{~cm}$ over the past 52 years. May through September growing season precipitation averages $22.9-\mathrm{cm}$ 


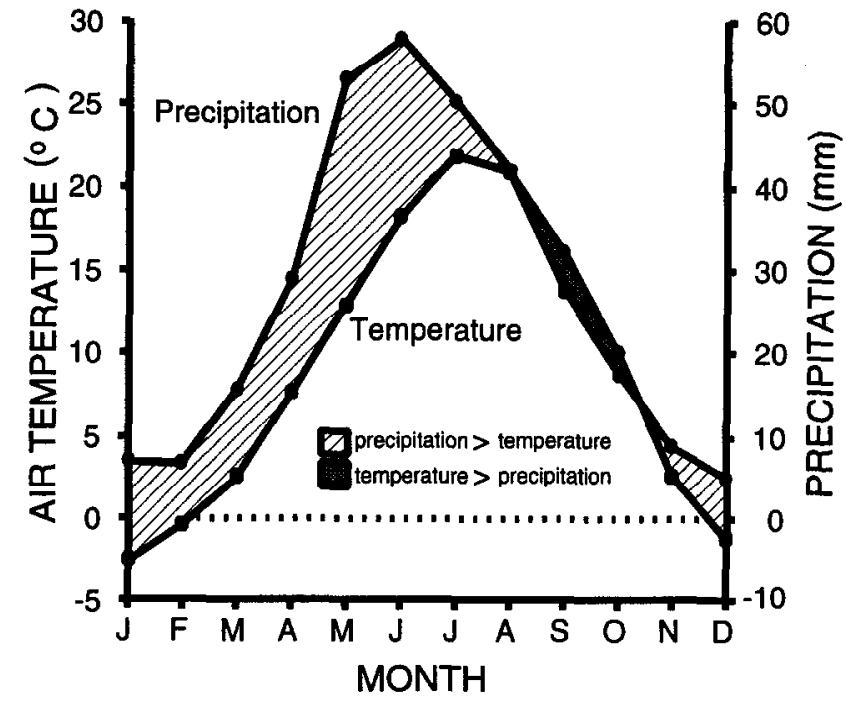

Fig. 1. Climatic diagram (Walter 1979) for the Central Plains Experimental Range, north-central Colorado ( $\left.40^{\circ} 49^{\prime} \mathrm{N} 107^{\circ} 47^{\prime} \mathrm{W}\right)$. Dotted areas indicate periods of relative drought and lined areas the relatively humid season.

year $^{-1}$, which is $71 \%$ of mean annual (Fig. 1). Maximum July temperatures average $30.6^{\circ} \mathrm{C}$ (std. dev. $2.0^{\circ} \mathrm{C}$ ) and January minimums average $-11.0^{\circ} \mathrm{C}$ (std. dev. $32 .^{\circ} \mathrm{C}$ ). Soil organic carbon ranges from 7 to $19 \mathrm{~g} \mathrm{~kg}^{-1}$, and sand content from 74 to $52 \%$ (Yonker et al. 1988). Soils are primarily Aridic Argiustolls, Ustollic Haplargids, Ustic Torriorthents, and Ustic Torrifluvents.

Four replicate pastures each of light, moderate, and heavy stocking rates (each approx. 130 ha), and ungrazed controls, were established in 1939 on areas that were not previously overgrazed (Klipple and Costello 1960). Two of the 4 replicates for each grazing treatment were in sandy-soil lowlands (half-sections numbers $8 \mathrm{~N}, 7 \mathrm{E}, 5 \mathrm{~W}$, and $7 \mathrm{~W}, 19 \mathrm{~W}, 19 \mathrm{E})$. The lowland replicates are dominated by the same grass-forb matrix, but also have a shrub component (fourwing saltbush-Atriplex canescens (Pursh) Nutt.), and are more productive than sites with fine-textured soils (Liang et al. 1989). One of the lowland replicates (half-sections $8 \mathrm{~N}, 7 \mathrm{E}$, $5 \mathrm{~W}$ ) also has a dry meadow of alkali sacaton (Sporobolus airoides (Torr.) Torr.) and western wheatgrass (Agropyron smithii Rydb.). One of the upland replicates (half-sections 23W, 23E, 15E) is upland blue grama-buffalo grass and the other (half-sections $15 \mathrm{~W}$, $22 \mathrm{E}, 21 \mathrm{~N}$ ) is blue grama-buffalo grass on ridges and buffalo grasswestern wheatgrass in swales. Each of the 4 replicates were originally chosen to represent different shortgrass "subtypes" (Klipple and Costello 1960).

Grazing occurred over a 6-month period spanning the growing season (June-November), with stocking rates for a particular year depending on the number of animals necessary to remove appoximately 20,40 , and $60 \%$ of forage production. From 1961 to 1991 , these areas have been managed so that approximately 45,35 , and $22 \mathrm{~g} \mathrm{~m}^{-2}$ of herbage were left at the end of the grazing season in lightly, moderately, and heavily grazed treatments, respectively. During this latter period, stocking averaged 15,21 , and 32 yearling heifers $130 \mathrm{ha}^{-1}$. Lengths of grazing periods varied depending on amount of forage produced in different years. From 1957 to 1971, 2 replicates (the upland sites), and from 1972 to present only 1 replicate (the bluegrama-buffalo grass site), of each of the original grazing-intensity pastures remained in the experimental design.

Forage production was estimated from 1939-1962 by harvesting end-of-season-standing-crop of live-plus-recent-dead forage within temporary moveable cages. From 1939-45, 24-caged plots $2.32 \mathrm{~m}^{2}$ were clipped immediately-above crown level in each pasture repli- cate; from 1946-62, 80-caged plots $0.19 \mathrm{~m}^{2}$ were clipped in each pasture replicate. Before 1949 , only blue grama and buffalo grass were sampled, and from 1949-1962 other grasses and sedges (Carex sp.) were included. No vegetation data were collected from 1963-1970, with subsequent estimates of production on various subsets of the 4 grazing treatments collected in 1970-73 (Sims et al. 1978), 1983-1990 (W.K. Lauenroth and D.G. Milchunas, unpublished data, with data for ungrazed treatment from an exclosure established in 1969 and for moderately grazed section 24 which is adjacent and vegetatively similar to the remaining lightly and heavily grazed replicate), 1988 (Milchunas et al. 1992), and 1989 (Varnamkhasti 1991). These latter investigators harvested all liveplus-dead vegetation in temporary cages at the end of the growing season except for cacti (primarily plains pricklypear). Long-term ungrazed treatments were not sampled for productivity prior to 1970. Data for green weights of all forage species collected in 1950-51 show forbs and shrubs contributing 20,16 , and $18 \%$, and sedges contributing 1,2 , and $3 \%$, of biomass in lightly, moderately, and heavily grazed treatments, respectively (Klipple and Costello 1960). Data for 1983-1990, sampling all vegetation except cacti, show forbs-plus-shrubs contributed an average of 22 and $11 \%$, and sedges contributed 4 and $8 \%$, of production in ungrazed and moderately grazed shortgrass steppe, respectively (W.K. Lauenroth and D.G. Milchunas, unpublished data). Therefore, the data collected from 1939-1948 and from 1949-1962 are quite similar, but data collected from 1970-1990 included a significant additional shrub and forb component.

We refer to plant production as 'forage production' rather than 'aboveground net primary production' because of the representation of cattle forage species in the sampling. End-of-seasonstanding-crop provides good estimates of aboveground net primary production in plant communities such as the shortgrass steppe, where there is a short growing season and species that account for the majority of production have similar phenologies (Lauenroth et al. 1986, Milchunas and Lauenroth 1992). Accurate estimates of net primary production by ${ }^{14} \mathrm{C}$ turnover show that end-of-season live-plus-recent-dead estimates of aboveground herbage underestimate aboveground net primary production by $16 \%$, whereas summation of positive increments in biomass from sampling throughout the growing season overestimates aboveground net primary production by 63\% (Milchunas and Lauenroth 1992).

The missing data in the 1960's and the different components of vegetation sampled in the early and late periods necessitated that data from 1939 through 1962 be treated separately from those collected from 1970 through 1991. Data from 1939 through 1962 were subjected to multiple stepwise regression analyses of forage production against: (1) grazing intensity (20, 40, 60\% removal); (2) years of grazing treatment; (3) warm-season precipitation (MaySeptember); (4) cool-season precipitation (October-April); (5) previous year's precipitation(October-September l-year-previous); (6) precipitation 2-years-previous; and (7) pasture relative productivity coefficient, and interaction and quadratic terms for the above variables. Although pasture relative productivity is not independent of the dependent variable, it was included because of the different productivities of the 4 replicate blocks of grazing intensity treatments. This 'normalization' of the data was necessary in order to decipher grazing-precipitation relationships; not including different pasture productivities resulted in regressions that were too noisy to discern effects of grazing or precipitation. Including relative productivity factors as an independent variable, rather than applying them to the dependent variable, was deemed a more visible manner of handling the problem; the effect of spatial variability across the landscape could be viewed in relation to grazingprecipitation effects. Separate regressions for each replicatepasture-block were not an alternative because not all blocks were 
sampled each year through 1962, which would again interfere with discerning precipitation responses between grazing treatments. If the replicate-blocks responded differently to grazing, this effect would appear as significant interaction terms, which were included in the model. Pasture relative productivity was calculated as the mean of all data for each particular block of pasture subtype divided by the mean of all data. Data from 50 years after initiating the treatments were used to substantiate predictions of the statistical model.

The regression model was examined for the presence of variables in interaction or quadratic terms. Quadratic and interaction terms were only included if (1) single terms were significant, and (2) single and interaction or quadratic terms were significant together. All levels of significance were considered $p \leq 0.05$. Casewise residual statistics included studentized residuals, Mahalanobis' distances, and Cook's distances. Casewise residuals were assessed in relation to cut-off values as defined in Rousseeuw and Leroy (1987). Outliers were removed in order to minimize potential of leverage points resulting in unreliable statistical models. Examination of normal probability plots indicated good agreement between observed and expected normality.

\section{Results}

Forage production across all 50 years averaged 71,68 , and $57 \mathrm{~g}$ $\mathrm{m}^{-2} \mathrm{yr}^{-1}$ for lightly, moderately, and heavily grazed treatments ( $\mathrm{n}=$ 89,97 , and 88), respectively (Fig. 2). The ungrazed treatments for which only 15 observation-years were available, averaged $75 \mathrm{~g} \mathrm{~m}^{-2}$ $\mathrm{yr}^{-1}$. Average warm-season precipitation during the years in which the ungrazed treatments were sampled was the same as that for the years in which the 3 grazed treatments were sampled, but averaged $2 \mathrm{~cm}$ more for cool-season precipitation. Distributions of production values were similar with the exception of a slight skew toward the high end for lightly grazed and toward the low end for heavily grazed; standard deviations were $20,22,21$, and $21 \mathrm{~g} \mathrm{~m}^{-2} \mathrm{yr}^{-1}$ for ungrazed, lightly, moderately, and heavily grazed treatments, respectively. Precipitation from 1939-1990 averaged $31.9 \mathrm{~cm} \mathrm{yr}^{-1}$, with $71 \%$ occurring during the May-September growing season. Coefficient of variation for warm-season precipitation was $35 \%$, and for cool-season precipitation was $39 \%$, compared with 26,32 , 31 , and $36 \%$ for forage production in the ungrazed, lightly, moderately, and heavily grazed treatments, respectively.

Visual examination of production and precipitation data from 1939-1990 indicated production varied widely both among years and within years among pastures (Fig. 3). Precipitation was often relatively constant for 2 to 3 years with large high or low years of precipitation interspersed. No clear temporal trends in forage production in the grazing treatments were evident.

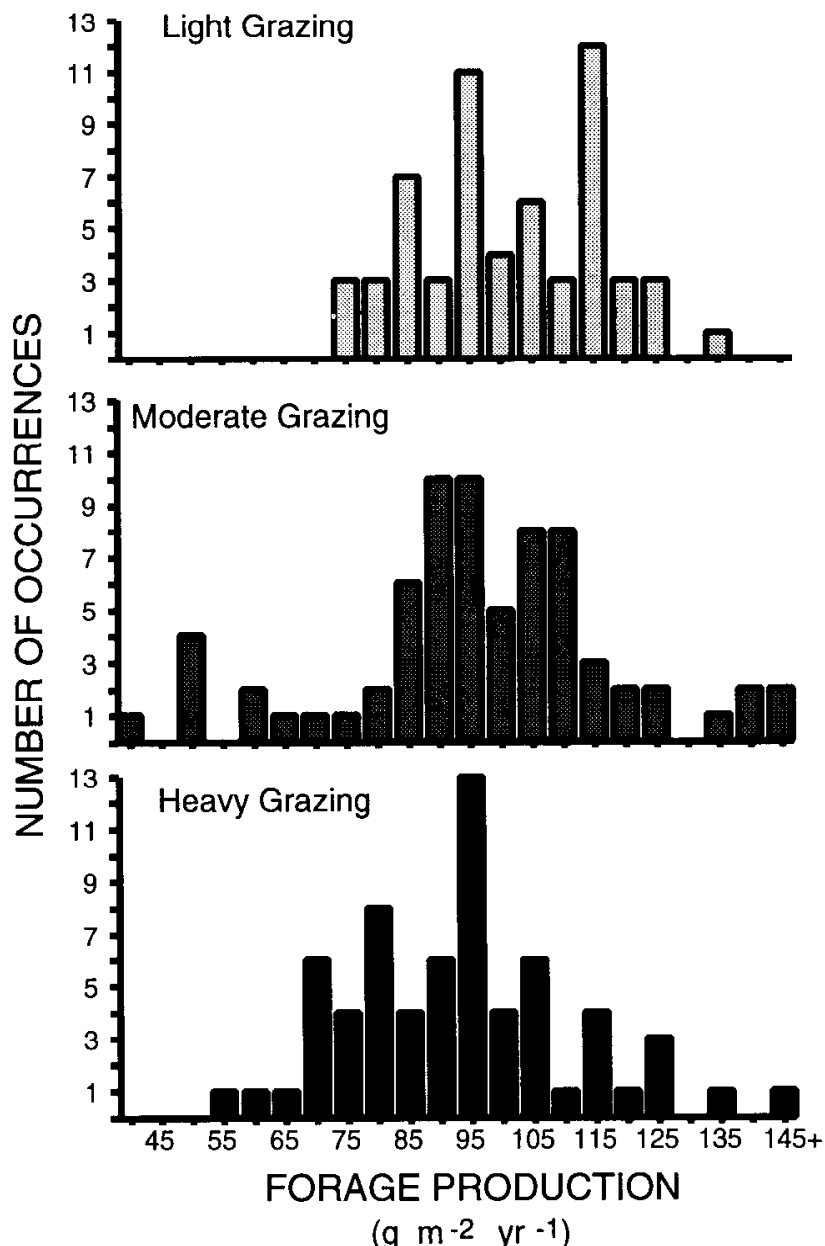

Fig. 2. Distributions (number of occurrences) of forage production $\left(\mathrm{g} \mathrm{m}^{-2}\right.$ $\mathrm{yr}^{-1}$ ) on lightly, moderately, and heavily grazed treatments in shortgrass steppe at the Central Plains Experimental Range. Ungrazed treatment was not included because of the few years of sampling; see text for mean and variance.

Multiple regression analysis showed that biotic, climatic, and edaphic factors were all important controls on forage production in this semiarid grassland. Cool-season precipitation (October through April), warm-season precipitation, grazing intensity, years of grazing treatment, and relative pasture productivity were significant independent variables and together explained $61 \%$ of the variance in forage production (Table 1). Precipitation 1 or 2

Table 1. Regression model for forage production $\left(\mathrm{g} \mathrm{m}^{-2} \mathrm{yr}^{-1}\right)$ of shortgrass steppe based upon 24 years of data for production in lightly, moderately, and heavily grazed treatments in $\mathbf{4}$ blocks of treatment pastures of different inherent productivity (see Materials and Methods Section for description of pasture relative productivity coefficient). Independent variables are ordered in accordance with their entry into the stepwise regression model, and all are significant at $p<0.05$ (constant $p-0.09$ ). Sensitivity is the difference in forage production when changing an independent variable from a low to a high value while holding other independent variables constant. See text for low-high values. $N=156$.

\begin{tabular}{|c|c|c|c|c|c|}
\hline Independent variable & Regression coefficient & Coefficient std. error & Incremental $R^{2}$ & Change in $R^{2}$ & Sensitivity \\
\hline (Cool-season precipitation) $^{2}$ & 1.2938 & 0.1923 & .21 & .21 & $-^{a}$ \\
\hline Pasture relative productivity & 59.6643 & 8.3296 & .36 & .15 & +18 \\
\hline (Grazing intensity) $^{2}$ & -0.0124 & 0.0055 & .43 & .07 & - $^{\mathrm{a}}$ \\
\hline Warm-season precipitation & 1.3032 & 0.2114 & .48 & .05 & +20 \\
\hline Cool-season precipitation & -17.7954 & 3.1999 & .55 & .07 & +64 \\
\hline Year & $-0.8125^{b}$ & 0.1681 & .60 & .05 & $-16^{\mathrm{b}}$ \\
\hline Grazing intensity & 0.6772 & 0.4418 & .61 & .01 & 13 \\
\hline Constant & 28.8181 & 16.9757 & & & \\
\hline
\end{tabular}

${ }^{a}$ Sensitivities are a function of both simple and quadratic term, values are provided under simple term.

${ }^{b}$ The coefficient for, and sensitivity to, year was primarily due to decreasing cool-season precipitation rather than to years of grazing treatment. See text for details. 


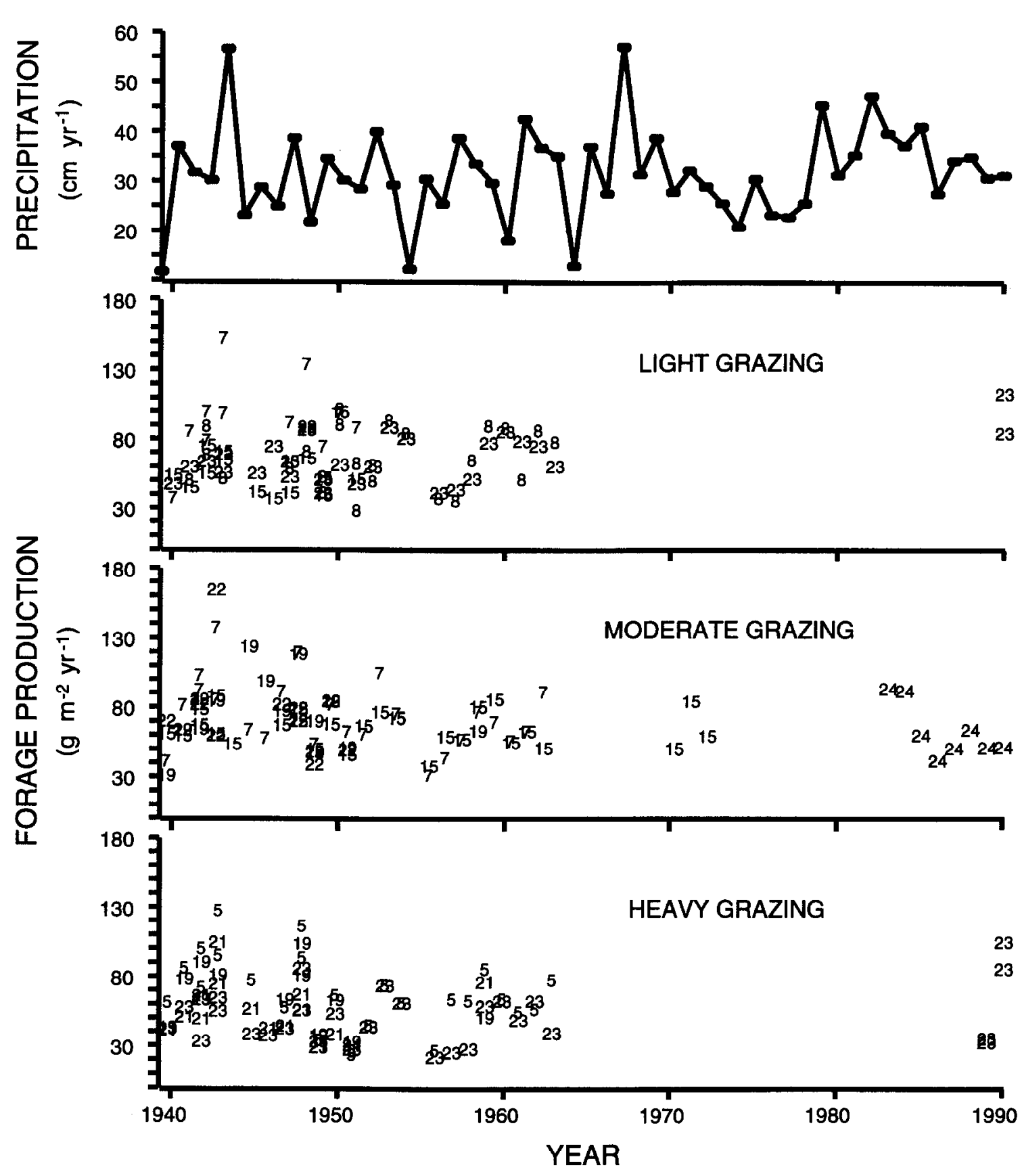

Fig. 3. Precipitation ( $\left.\mathrm{cm} \mathrm{yr}^{-1}\right)$ and forage production $\left(\mathrm{g} \mathrm{m}^{-2} \mathrm{yr}^{-1}\right)$ in lightly, moderately, and heavily grazed treatments from 1939 through 1990 at the Central Plains Experimental Range, northern shortgrass steppe. Numbers for points in production graphs represent the individual pastures by section number (each pasture was a one-half section area; see Methods). See text for description of differences in sampling regimes between studies, and for data for ungrazed treatment.

years prior to sampling forage production, and interaction terms, did not significantly enter into the regression model. Cool-season precipitation, rather than warm-season precipitation, and relative pasture productivity were factors contributing the greatest to the cumulative $R^{2}$. Grazing intensity, and its quadratic, and years of grazing treatment together contributed only 0.14 to the cumulative $R^{2}$ of 0.61 .

Because it is impossible to graph in 6 dimensions, we examined sensitivities of change in forage production to changes in independent variables from low to high values chosen to represent the observed ranges. Based upon the regression model, forage production was most sensitive to differences in cool-season precipitation from dry to wet years; predicted increase in forage production when cool-season precipitation increased from $6 \mathrm{~cm}$ to $14 \mathrm{~cm}$ was $64 \mathrm{~g} \mathrm{~m}^{-2} \mathrm{yr}^{-1}$ (Fig. 4a). In comparison, varying warm-season precip- itation from $15 \mathrm{~cm}$ to $30 \mathrm{~cm}$ increased production $20 \mathrm{~g} \mathrm{~m}^{-2} \mathrm{yr}^{-1}$ (Fig. 4b). The sensitivity of forage production to cool-season precipitation (Fig. 4a) was low during very dry years and increased as cool-season precipitation increased. Average cool-season precipitation from 1939-1990 was $8.7 \mathrm{~cm}$. Increasing cool-season precipitation from 7 to $8 \mathrm{~cm}$ was predicted to increase production $1.6 \mathrm{~g}$ $\mathrm{m}^{-2} \mathrm{yr}^{-1}$ compared with an increase of $6.8 \mathrm{~g} \mathrm{~m}^{-2} \mathrm{yr}^{-1}$ for an increase from 9 to $10 \mathrm{~cm}$. In contrast, forage production increased $1.3 \mathrm{~g}$ $\mathrm{m}^{-2} \mathrm{yr}^{-1}$ for each additional centimeter for warm-season precipitation.

In comparison to the 64 and $20 \mathrm{~g} \mathrm{~m}^{-2} \mathrm{yr}^{-1}$ increase in production for increasing cool- and warm-season precipitation, respectively, increasing other independent variables in the regression model from the low to the high range of values resulted in $+18,-16$, and $-13 \mathrm{~g} \mathrm{~m}^{-2} \mathrm{yr}^{-1}$ of production for changing the pasture relative pro- 


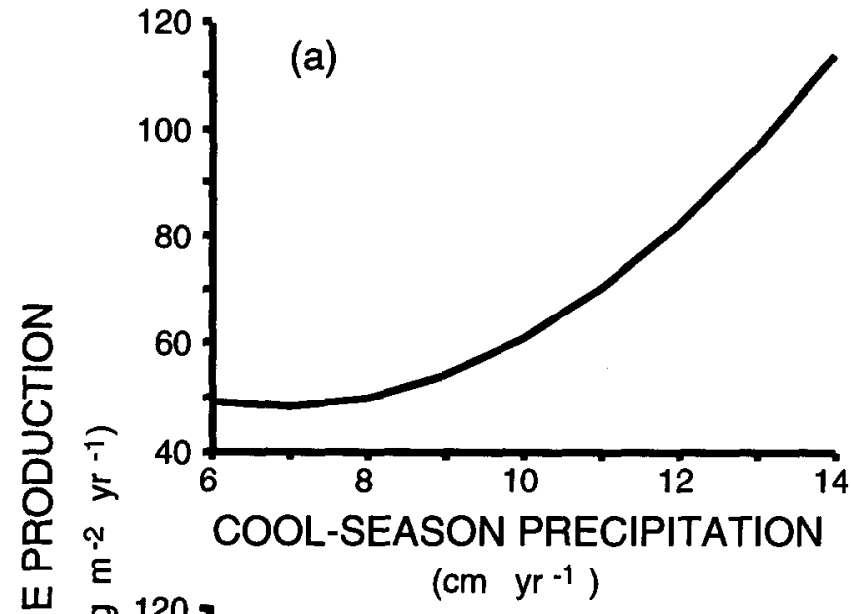

$\frac{1}{0}$

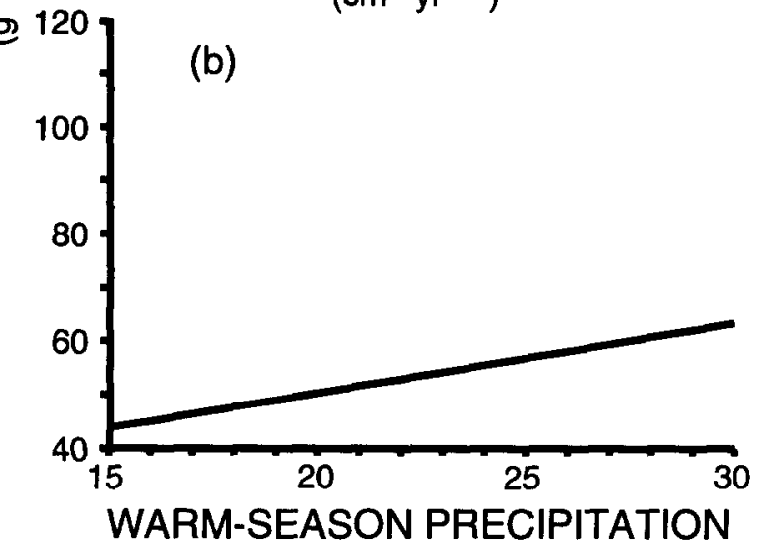

(cm $\mathrm{yr}^{-1}$ )

Fig. 4. Sensitivity of change in the regression model of forage production $\mathrm{g}$ $\mathrm{m}^{-2} \mathrm{yr}^{-1}$ ) to changes in a) cool-season and b) warm-season precipitation. Ranges for precipitation were chosen to provide examples of reasonable low-high values; other variables in the regression model were held constant at average values. See Table 1 for description of regression model.

ductivity coefficient from 0.85 to 1.15 , duration of grazing treatment from 5 to 25 years, and grazing intensity from 20 to $60 \%$ utilization, respectively. There were small effects of long-term grazing treatment intensities up to $35 \%$ consumption of forage on forage production, with increasingly greater negative effects as levels of removal by cattle increased to $60 \%$ (Fig. 5). Increasing grazing intensities from 20 to $60 \%$ decreased production $2.5 \%$ under conditions of high precipitation and 5 years of treatment, compared with a decrease of $12 \%$ under the opposite set of conditions (low precipitation and 25 years of treatment).

The regression analyses indicate (1) no difference in forage production under grazing intensities removing 20 to $35 \%$ biomass, (2) decreased production from 35 to $60 \%$ removal intensities, but (3) decreased production on all grazing treatments from 1939 to mid1960 's. The decrease in production with time may be due to grazing or to a pattern of decreasing precipitation through time. Regressions of precipitation over time showed no significant decline in warm-season precipitation, but a slope of $-0.19 \mathrm{~cm} \mathrm{yr}^{-1}$ for coolseason precipitation $\left(r^{2}=0.19\right.$, year significant at $p=0.03$, and slope significantly different from 0 ). This estimates a decline in cool-season precipitation from 10.8 to $6.6 \mathrm{~cm}$ over 25 years. The forage production model would predict a $19.7 \mathrm{~g} \mathrm{~m}^{-2}$ decrease in production due to this decline in cool-season precipitation compared to a decline of $16 \mathrm{~g} \mathrm{~m}^{-2}$ for 25 years of grazing treatment. Therefore, it is likely that the decline in production with years of grazing predicted by the regression model is a consequence of the

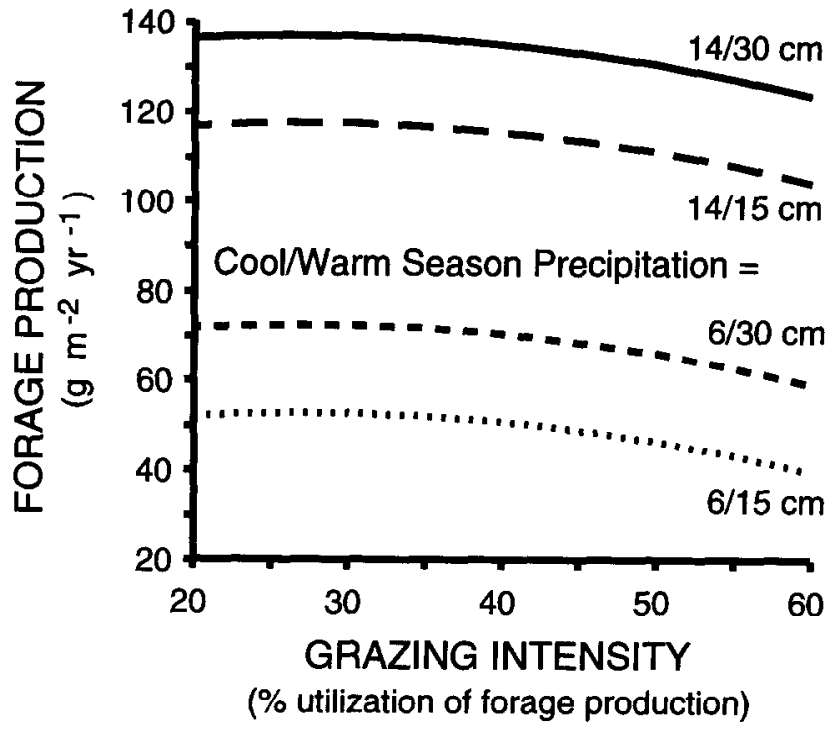

Fig. 5. Sensitivity of change in the regression model of forage production $\left(\mathrm{g} \mathrm{m}^{-2} \mathrm{yr}^{-1}\right)$ to changes in grazing intensity (20 to $60 \%$ utilization), duration of grazing treatment ( 5 and 25 years), and cool- and warmseason precipitation ( 6 and 14 , and 15 and $30 \mathrm{~cm} \mathrm{yr}$ ). Ranges for variables were chosen to provide examples of reasonable low-high values. Decreased production with increasing years of treatment is not considered a grazing effect, because cool-season precipitation declined over the years of measurement (see text for additional explanation).

decline in cool-season precipitation through the years, because there was no significant grazing intensity by years of grazing interaction. The regression model indicates, however, that heavy grazing ( $60 \%$ consumption of forage production) has resulted in a $3 \%$ decrease in production in relatively wet years to a $12 \%$ reduction in relatively dry years.

Recent production data for the long-term grazing treatments had to be left out of the regression analyses because of the outliereffect in X-space and because of different proportions of the total species that were sampled. Estimates of aboveground primary production (sampling all species) obtained in 1989 (after 50 years of grazing treatments) indicated that heavily grazed treatments produced $18 \%$ less than lightly grazed treatments in this year of average precipitation (Varnamkhasti 1991). Supplementary water added to plots to simulate a wet year resulted in large increases in production in all treatments, and heavily grazed treatments produced only $5 \%$ less than lightly grazed treatments under this wetcondition. Regression model predictions of the reductions due to heavy grazing for the average- and wet-year conditions when the above empirical data were collected were -19 and $-16 \%$, respectively (using 1 year of treatment in model, assuming year effect is due to declining cool-season precipitation through years for data used in model). Predictions of the regression model constructed from earlier data were very similiar to the empirical data for the year of average precipitation, slightly overestimated the effect of heavy grazing in the wet year and depicted the less negative effect of heavy grazing under wet-year compared to drier conditions.

\section{Discussion and Conclusions}

Long-term data sets are valuable for assessing year-to-year variability in parameters and their temporal trends. Often, however, methods and research objectives change through time, which places limitations on analyses and interpretations of the data. The data and analyses presented here may be useful in separating the relative effects of climatic, edaphic, and biotic controls on plant production in shortgrass steppe, but should not be considered as absolute estimates of production or as representing all factors 
which may affect production in the different grazing treatments. The reader is referred to Ashby et al. (1993) for end-of-seasonstanding crops of all functional groups in the grazing treatments for 1941-42, 1950-51, and 1991-92, and to Milchunas and Lauenroth (1992) for estimates of bias in traditional harvest estimates of net primary production. Williamson et al. (1989), Milchunas et al. (1992), and Varnamkhasti (1991) examine how current-season herbivory, grazing, or defoliation affect estimates of production through compensatory regrowth mechanisms and illustrate how this may influence relative differences between treatments in different years. Further, a decline in cool-season precipitation through time was confounded with years of grazing treatment in the regression model. We therefore cannot use the model as a tool for predicting absolute values but view it as a useful means to decipher the relative importance of climatic, edaphic versus biotic controls on forage production. Sensitivity analyses suggest a ranking of importance of climatic $>$ edaphic $>$ biotic.

Early reports (using data through 1953) of the response of shortgrass steppe vegetation to long-term grazing treatments at the CPER (Klipple and Costello 1960) concluded that under lightly grazed treatment "Highly palatable species...increased in frequency of occurrence. Dominant grasses increased in vigor and yield....Heavy grazing caused a reduction in the total production of vegetation growth and production of most of the better forage plants." Klippe and Bement (1961) concluded that most of the improvement in forage production from light grazing occurred during the first 5 to 7 years with little added improvement observed after 7 years. Our analyses using data for additional years of grazing treatment do not alter early conclusions when placed in a proper context. The 'increase' in yield under light grazing that the early authors refer to is probably in comparison to the moderately grazed conditions before initiating the long-term grazing treatments rather than to ungrazed treatments. Although species composition data were collected, productivity data were not collected in ungrazed treatments. Even species composition of ungrazed and lightly grazed treatments were very similar at the time of last sampling (1940-42, 1946-48, 1952-53) by these early authors. Differences in species composition of ungrazed versus heavily grazed treatments were still small after nearly 50 years of treatment (Milchunas et al. 1989), and ungrazed rather than heavily grazed communities were more similar to disturbed communities (Milchunas et al. 1990).

Lauenroth and Milchunas (1991) calculated net losses of nitrogen from shortgrass steppe due to cattle via volatilization from urine, eructation of rumen gases, and animal harvest to be $376 \mathrm{~g}$ $\mathrm{ha}^{-1} \mathrm{yr}^{-1}$. D.G. Milchunas and W.K. Lauenroth (unpublished data) observed lower soil carbon and nitrogen on heavily grazed than ungrazed shortgrass steppe. Lower production on heavily grazed shortgrass steppe may be due to lower soil fertility. Plant mortality is probably not a reason for lower production because plant basal cover is greater in heavily grazed than ungrazed treatments (Milchunas et al. 1989).

These analyses do not generally support Le Houérou's (1984) and Le Houérou et al.'s (1988) concepts of rain-use-efficiency under pristine versus grazed conditions. Compared with light grazing intensity, rain-use-efficiency declined with heavy grazing intensity, but not with moderate grazing. Le Houérou predicted increasing variability in rain-use-efficiency with grazing. Absolute variabilities in production (standard deviations) across treatments were very similar, although coefficients of variation were lowest for ungrazed and highest for heavily grazed grassland. In terms of vegetation available to consumers, all 4 grazing treatments displayed a similar degree of variability. Further, no grazing treatment by precipitation interaction was observed to support our hypothesis of a decreasing capacity for response to wet years with increasing grazing intensity.

Precipitation was the most influential variable in accounting for variability in production at this shortgrass steppe site. Lauenroth and Sala (1992) analyzed average production across the entire CPER regardless of grazing treatment and found significant relationships between production and both annual and growingseason precipitation. These analyses indicate that above average amounts of cool-season precipitation were most effective in promoting high production. This may be because a smaller fraction of precipitation during the cool season is likely to be lost to evaporation compared to the warm season, or that high total production corresponds to years with a greater contribution by cool-season (C3) plants. De Wit (1958) suggested that a given amount of precipitation results in greater production as evaporative demand of the atmosphere decreases. Mean maximum air temperatures in March and April at the CPER are 10 and $15^{\circ} \mathrm{C}$, respectively, compared to 26 and $31^{\circ} \mathrm{C}$ in June and July (see also Fig. 1). The regression model predicted a greater increase in production per unit of cool- than warm-season precipitation, but only when coolseason precipitation was greater than average. Increases in production with increasing precipitation were 0 or very small when coolseason precipitation was below average, but increases in production were linear throughout the range of increasing warm-season precipitation.

Small rainfall events are a large portion of precipitation events in the shortgrass steppe (Sala and Lauenroth 1982, Lauenroth and Milchunas 1991). While the dominant species of shortgrass steppe are capable of responding rapidly to, and utilizing, small rainfall events (Sala and Lauenroth 1982), plant growth and water uptake are minimal during March and April. Small events falling at this time would be largely lost to evaporation even though temperatures are relatively low. Large events during this period probably accumulate below the evaporative zone and provide a source of water for early spring growth even during precipitation-free periods that may occur during May or June. Small rain events may be more effectively utilized during the warm season when roots are active than during the cool season, but the effectiveness of large events may be greater during the cool season.

The shortgrass steppe has a long evolutionary history of grazing by large herbivores and of semiaridity (Milchunas et al. 1988). Plant communities are resistant to grazing (Milchunas et al. 1990) and well adapted to drought through mechanisms for fast recovery (Lauenroth et al. 1987) and efficient utilization of precipitation (Sala and Lauenroth 1982). Thus while unusual for many other systems, it may not be unusual that productivity of shortgrass steppe is more sensitive to variability in precipitation than to differences in long-term grazing intensities.

\section{Literature Cited}

Ashby, M.M., R.H. Hart, and J.R. Forwood. 1993. Plant community and cattle responses to fifty years of grazing on shortgrass prairie. USDAARS, Rangeland Resources Res. Unit, RRRU-1, Crops Res. Lab., Fort Collins, Colo.

De Wit, C.T. 1958. Transpiration and crop yields. Meded. 59, Scheikundig Onderzoek Landbouwgewassen, Wageningen, The Netherlands.

Klipple, G.E., and R.E. Bement. 1961. Light grazing: is it economically feasible as a range improvement practice? J. Range Manage. 14:57-62.

Klipple, G.E., and D.F. Costello. 1960. Vegetation and cattle response to different intensities of grazing on shortgrass ranges on the central Great Plains. USDA Tech. Bull. 1216. US Gov. Print. Off., Washington, D.C. Lauenroth, W.K. and D.G. Milchunas. 1991. The shortgrass steppe, p. 183-226. In: R.T. Coupland (ed.), Natural grasslands, introduction and western hemisphere. Ecosystems of the World 8A, Elsevier, Amsterdam.

Lauenroth, W.K., H.W. Hunt, D.M. Swift, and J.S. Singh. 1986. Estimating aboveground net primary production in grasslands: A simulation approach. Ecol. Modeling 33:297-314. 
Lauenroth, W.K., and O.E. Sala. 1992. Long term forage production of North American shortgrass steppe. Ecol. Appl. 2:397-403.

Lauenroth, W.K., O.E. Sala, D.G. Milchunas, and R.W. Lathrop. 1987. Root dynamics of Bouteloua gracilis during short-term recovery from drought. Functional Ecol. 1:117-124.

Le Houérou, H.N. 1984. Rain use efficiency: A unifying concept in aridland ecology. J. Arid Environ. 7:213-247.

Le Houérou, H.N., R.L. Bingham, and W. Skerbek. 1988. Relationship between the variability of primary production and the variability of annual precipitation in world arid lands. J. Arid Environ. 15:1-18.

Liang, Y.M., D.L. Hazlett, and W.K. Lauenroth. 1989. Biomass dynamics and water use efficiencies of five plant communities in the shortgrass steppe. Oecologia (Berlin) 80:148-153.

Milchunas, D.G., and W.K. Lauenroth. 1989. Three-dimensional distribution of plant biomass in relation to grazing and topography in the shortgrass steppe. Oikos 55:82-86.

Milchunas, D.G., and W.K. Lauenroth. 1992. Carbon dynamics and estimates of primary production by harvest, ${ }^{14} \mathrm{C}$ dilution, and ${ }^{14} \mathrm{C}$ turnover. Ecology 73:593-607.

Milchunas, D.G., W.K. Lauenroth, and P.L. Chapman. 1992. Plant competition, abiotic, and long- and short-term effects of large herbivores on demography of opportunistic species in a semiarid grassland. Oecologia (Berlin) 92:520-531.

Milchunas, D.G., W.K. Lauenroth, P.L. Chapman, and M.K. Kazempour. 1990. Community attributes along a perturbation gradient in a shortgrass steppe. J. Veg. Sci. 1:375-384.
Milchunas, D.G., W.K. Lauenroth, P.L. Chapman, and M.K. Kazempour. 1989. Effects of grazing, topography, and precipitation on the structure of a semiarid grassland. Vegetatio 80:11-23.

Milchunas, D.G., O.E. Sala, and W.K. Iauenroth. 1988. A generalized model of the effects of grazing by large herbivores on grassland community structure. Amer. Natur. 132:87-106.

Rousseeuw, P.J., and A.M. Leroy. 1987. Outlier diagnostics, p. 216-247. In: Robust regression and outlier detection. Wiley Series in Probability and Mathematical Statistics, N.Y.

Sala, O.E. and W.K. Lauenroth. 1982. Small rainfall events: an ecological role in semiarid regions. Oecologia (Berlin) 53:301-304.

Sala, O.E., W.K. Lauenroth, and W.J. Parton. 1992. Long-term soil water dynamics in the shortgrass steppe. Ecology 73:1175-1181.

Sims, P.L., J.S. Singh, and W.K. Lauenroth. 1978. The structure and function of ten western North American grasslands. I. abiotic and vegetational characteristics. J. Ecol. 66:251-285.

Varnamkhasti, A.S. 1991. A boveground production and rain use efficiency responses to long-term grazing, defoliation, and rainfall. M.S. Thesis, Colorado State Univ., Ft. Collins, Colo.

Walter, H. 1979. Vegetation of the earth and ecological systems of the geo-biosphere. 2nd Ed. Springer-Verlag, N.Y.

Williamson, S.C., J.K. Detling, J.L. Dodd, and M.I. Dyer. 1989. Experimental evaluation of the grazing optimization hypothesis, J. Range Manage. 42:149-152.

Yonker, C.M., D.S. Schimel, E. Paroussis, and R.D. Heil. 1988. Patterns of organic carbon accumulation in a semiarid shortgrass steppe, Colorado. Soil Sci. Soc. Amer. J. 52:478-483. 